\title{
Determination of Flavonoids in the Leaves of Hawthorn (Crataegus Azarolus ) of Iraqi Kurdistan Region by HPLC Analysis
}

\author{
Baram Ahmed Hamahameen and Banaz Jamal
}

\begin{abstract}
Flavonoids content of two types of hawthorn leaves (crataegus azarolus) which grows in Iraqi Kurdistan region (season 2011) including Zalan and Qaradax, were determined by RP-HPLC technique. The percentages of major flavonoids contents were found to be Hypersoide and Vitexin-rahmnose (28.12-30.26 \%), (30.30-18.00\%), respectively and these results were compared with ratio of them in the hawthorn fruits of the same plants in which these two majors (Hypersoide and Vitexin-rahmnose) flavonoids became very low but some other flavonoids like Querecetin, Nonacosan-10-01 and Apigenin show high percentage $(\mathbf{1 8 . 2 4 \%}, \mathbf{1 3 . 7 2 \%}$ and $11.98 \%$ respectively) in Hawraman hawthorn and in Qaradax hawthorn some other types are dominated like Nonacosan-10-01, Kaempferol and Querecetin having following ratio $(18.10 \%$, $16.59 \%$ and $15.51 \%$ respectively). Divert compounds of flavonoids composition were analyzed also by HPLC technique in these two types of hawthorn leaves, different ratio of : 1Neoategolic acid, 2-Kaempferol (I), 3-Querecetin, 4-Nonacosan10-01 (II), 5-Apigenin(III), 6-Luteolin(IV), 7-Rutin(V), 8-Hypersoide(VI) and 9-Vitexin-rahmnose (VII), these compounds have main physiological role and pharmaceutical effect on the fruits of Hawthorn and also same role on the animal and human physiology.
\end{abstract}

Index Terms-Crataegus Azarolus, flavonoids, HPLC analysis, Hawthorn.

\section{INTRODUCTION}

Our previous work in this field indicates the percentage of fatty acids and triterpinoids contents of hawthorn fruits but in this new work we want to show the flavonoids ration in hawthrorn leaves of the same region, Fig. 1[1].

Previous literature studies[2] identified hyperoside (HP), isoquercitrin (IQ) and epicatechin (EC) to be the major active flavonoid components of the hawthorn phenolic extract from hawthorn fruits demonstrating inhibitory effect on in vitro $\mathrm{Cu}(+2)$-mediated low density lipoproteins oxidation. Hawthorn leaves from two different part of Kurdistan region of Iraq ( Zalan and Qaradagh) have been collected, in order to study and investigate the flavonoids content by means of HPLC methods, the contents of the flavonoids in hawthorn leaves extract that disposed through different conditions were measured and compared and analyzed by using the

Manuscript received October 12, 2012; revised December 5, 2012

Baram Ahmed Hamahameen is with the Department of Chemistry, School of Science, Faculty of Science\&Science Education, University of Sulaimani (e-mail: baramjaff@yahoo.com).

Banaz Jamal is with the Department of Field Corps, Faculty of Agriculture, university of Sulaimani ultraviolet-visible spectrophotometry with two methods. Results: the concentration of the flavonoids was $86.15 \%$ by using the $\mathrm{Al}\left(\mathrm{NO}_{3}\right)_{3}(510 \mathrm{~nm})$, and $\mathrm{AlCl}_{3}(272 \mathrm{~nm})$ was $35.19 \%$ [3]. Hawthorn extract for treating chronic heart failure has been used by meta-analysis of randomized trials by a group of researchers and the results shows there is a significant benefit from hawthorn extract as an adjunctive treatment for chronic heart failure [4].

Jakstas et al. [5] worked on hawthorn flavonoids contents of some Lithuanian hawthorn they founded: Akmene (V1, V2, V3), Kedainiai (S1, S2, S3), Klaipeda (M1), Lazdijai (D1, D2, D3) and Vilnius (VL1, VL2) components were extracted with ethanol and flavonoids were measured by spectroscopic method and by high performance liquid chromatography. The ratio 0.72 to $1.89 \%$ of flavonoids were founded in the hawthorn buds. The dominating flavonoid is vitexin-2-O-rhamnosid (6.72-10.91 milligrams in one gram of dried crude drug). Other flavonoids are: vitexin: 0.88-6.53 $\mathrm{mg} / \mathrm{g}$, hyperosid: $0.85-2.70 \mathrm{mg} / \mathrm{g}$, rutin: $0.72-2.10 \mathrm{mg} / \mathrm{g}$ and quercitrin: $0.82-1.01 \mathrm{mg} / \mathrm{g}$.

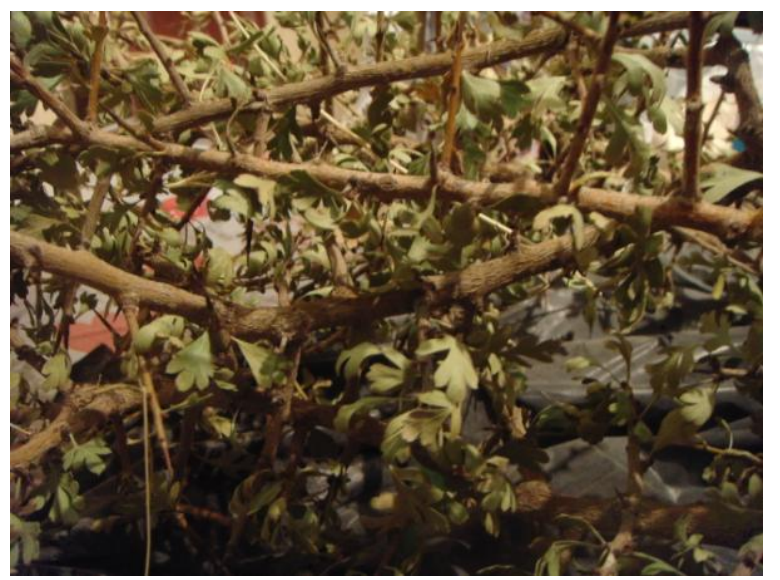

Fig. 1. Hawthorn leveas of Zalan,Kurdistan North of Iraq Kaempferol.<smiles>O=c1c(O)c(-c2ccc(O)cc2)oc2cc(O)cc(O)c12</smiles>

Kaempferol (I) 
<smiles>O=c1cc(-c2ccc(O)cc2)oc2cc(O)cc(O)c12</smiles><smiles>O=c1cc(-c2ccc(O)c(O)c2)oc2cc(O)cc(O)c12</smiles>

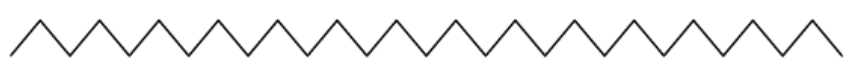

Nonacosane (II)

Rutin(V): Rutin, also called rutoside, quercetin-3-Orutinoside and sophorin, is the glycoside between the flavonol quercetin and the disaccharide rutinose $(\alpha$-L-Rhamnopyranosyl- $(1 \rightarrow 6))-\beta$-D-glucopyranose). In fava d'anta, the synthesis is done via a rutin synthase activity[6], Rutin inhibits platelet aggregation[7], Luteolin IV shows anti-inflammatory activity in some animal and in vitro models[8], Rutin, as ferulic acid, can reduce the cytotoxicity of oxidized LDL cholesterol and lower the risk of heart disease and Rutin is also an antioxidant[9].

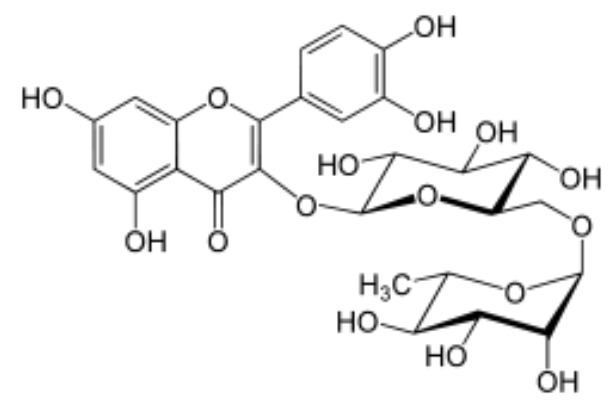

Rutin (V)<smiles>O=c1c(OC2O[C@H](CO)[C@@H](O)[C@H](O)[C@H]2O)c(-c2ccc(O)c(O)c2)oc2cc(O)cc(O)c12</smiles>

Hypersoide (VI)

\section{CANCER BENEFIT}

Vitexin is a flavonoid glycoside found in certain herbs including hawthorn herb.

Vitexins, nature-derived lignan compounds, induce apoptosis and suppress tumor growth. Lignans such as secoisolari- ciresinol diglucoside in flaxseed, are metabolizes to bioactive mammalian lignans of END and ENL. Because mammalian lignans have chemical structural similarity to the natural estrogen, they are thought to behave like selective estrogen receptor modulators and therefore have anticancer effect against hormone-related cancers. We isolated a series of lignan compounds, named as Vitexins, from the seed of Chinese herb Vitex Negundo. We purified several Vitexin lignan compounds. Cytotoxic and antitumor effects were analyzed in cancer cells and in tumor xenograft models. In vivo metabolism of Vitexins was determined in rat. Vitexin is a class of nature lignan compounds, whose action and anticancer effect is mediated by the mechanisms different from the classic lignans. Vitexin-induced antitumor effect and cytotoxic activity is exerted through proapoptotic process, which is mediated by a decreased $\mathrm{Bcl}-2 / \mathrm{Bax}$ ratio and activation of caspases.<smiles>O=c1cc(-c2ccc(O)cc2)oc2c([C@@H]3O[C@H](CO)[C@@H](O)[C@H](O)[C@H]3O)c(O)cc(O)c12</smiles>

Vitexin important (VII)

\section{A. Material and Method}

Two types of hawthorn [cartaegus azarolus] leaves, [ Zalan and Qaradax] were harvested by hand in its optimum state for two consecutive seasons in 2011 in Kurdistan region -north Iraq, Zalan and Qaradax Fig. 1. After a morphological and chemical characterization, the samples were prepared for determination of their flavonoids constituents.

\section{B. Preparation of the Sample for the Determination of Flavonoid Contents in Hawthorn Leaves and Fruits}

The two types of hawthorn leaves Zalan and Qaradax were oven-dried at $50{ }^{\circ} \mathrm{C}$ for $18 \mathrm{~h}$ and ground through a wiley mill to pass a 30-40 mesh screen, and stored tightly at $4{ }^{0} \mathrm{C}$. $10 \mathrm{~g}$ of the samples were dissolved in $30 \mathrm{ml}$ methanol ,then agitated in ultra sonic bath for 30minutes, then extract were filtered on whatman filter paper $0.5 \mu \mathrm{m}$ to remove the fibers and un-dissolved texture, the extract were pre-concentrated by stream of $\mathrm{N} 2$ to about $0.5 \mathrm{ml}$ and then complete the volume to $1 \mathrm{ml}$ by the mobile phase, then $20 \mathrm{ul}$ of the aqueous filtrate were injected to HPLC column[10], Table I. 
TABLE I: FLAVONOIDS CONTENTS IN ZALAN HAWTHORN LEAVES

\begin{tabular}{|l|l|c|c|c|c|c|c|c|}
\hline no & Flavor- noids & $\mathbf{R t} / \mathbf{m}$ & area/standard & df & area/sample & conc. $\boldsymbol{\mu g} / \mathbf{m l}$ & conce. of sample & $\%$ \\
\hline 1 & Neoategolic acid & 0.98 & 30978 & 3 & 10232 & 25 & 24.7724 & 2.99447124 \\
\hline 2 & Kaempferol & 1.83 & 34390 & 3 & 16662 & 25 & 36.3376 & 4.39246131 \\
\hline 3 & Querecetin & 3.06 & 39894 & 3 & 12329 & 25 & 23.1783 & 2.80177502 \\
\hline 4 & Nonacosan-10-01 & 4.07 & 41009 & 3 & 15236 & 25 & 27.8646 & 3.36825354 \\
\hline 5 & Apigenin & 4.89 & 62694 & 3 & 65552 & 25 & 78.4190 & 9.47922774 \\
\hline 6 & Luteolin & 5.68 & 47283 & 3 & 45375 & 25 & 71.9735 & 8.70010721 \\
\hline 7 & Rutin & 6.49 & 51741 & 3 & 56148 & 25 & 81.3881 & 9.83812788 \\
\hline 8 & Hypersoide & 7.39 & 60515 & 3 & 187712 & 25 & 232.6431 & $\mathbf{2 8 . 1 2 1 7 2 7 1}$ \\
\hline 9 & Vitexin-rahmnos & 8.4 & 51494 & 3 & 172124 & 25 & 250.6952 & $\mathbf{3 0 . 3 0 3 8 4 8 9}$ \\
\hline & Total & & & & & & 827.2719 & \\
\hline
\end{tabular}

TABLE II: FLAVONOIDS CONTENTS IN QARADAX HAWTHORN LEAVES

\begin{tabular}{|l|l|c|c|c|c|c|c|c|}
\hline no & Flavor- noids & $\mathbf{R t} / \mathbf{m}$ & area/standard & df & area/sample & conc. $\boldsymbol{\mu g} / \mathbf{m l}$ & conce. of sample & \% \\
\hline 1 & Neoategolic acid & 0.98 & 30978 & 3 & 13960 & 25 & 33.798 \\
\hline 2 & Kaempferol & 1.83 & 34390 & 3 & 42689 & 25 & 93.099 & 9.73284170 \\
\hline 3 & Querecetin & 3.06 & 39894 & 3 & 31704 & 25 & 59.602 & 6.23106569 \\
\hline 4 & Nonacosan-10-01 & 4.07 & 41009 & 3 & 41301 & 25 & 75.534 & 7.89654732 \\
\hline 5 & Apigenin & 4.89 & 62694 & 3 & 62694 & 25 & 75.0000 & 7.840718364 \\
\hline 6 & Luteolin & 5.68 & 47283 & 3 & 0 & 25 & 0.0000 \\
\hline 7 & Rutin & 6.49 & 51741 & 3 & 108875 & 25 & 157.81 \\
\hline 8 & Hypersoide & 7.39 & 60515 & 3 & 233590 & 25 & 16.4986801 \\
\hline 9 & Vitexin-rahmnose & 8.4 & 51494 & 3 & 118224 & 25 & $\mathbf{3 0 . 2 6 5 4 4 4 9}$ \\
\hline & Total & & & & & 17.0013416 \\
\hline
\end{tabular}

\section{RESULT AND DISCUSSION}

Hawthorn leaves flavonoids contents of [Zalan and Qaradax] were determined and it shown that the content of Hypersoide and Vitexin-rahmnose are (28.12-30.26\%), (30.30-18.00\%), respectively. The characteristics properties of the flavonoids compared with their contents in their fruits which shown to be very different, there are some other flavonoids like Querecetin, Nonacosan-10-01 and Apigenin show high percentage $(18.24 \%, 13.72 \%$ and $11.98 \%$ respectively) in Hawraman hawthorn and in Qaradax hawthorn some other types are dominated like Nonacosan-10-01, Kaempferol and Querecetin having following ratio $(18.10 \%, 16.59 \%$ and $15.51 \%$ respectively) as in Tables I-IV, in addition there is a specific flavonoid Luteolin which have some mysterious results exist in the hawthorn leaves but disappear in its fruit (Zalan one) but in Qaradax simple this flavonoid is $0 \%$ in its leave but it appear in the hawthorn fruit of this Town.

The HPLC analysis of fatty acid composition in the two types of hawthorn leaves are presented in Table I and II from the result the each types of hawthorn leaves contain high percentage of Hypersoide and Vitexin-rahmnose, which is about $28.12 \%$ and $30.30 \%$ respectively in a Zalan hawthorn leaves and about $30.26 \%$ and $18 \%$ respectively in hawthorn leaves of Qaradax.

\section{CAlculation}

Concentration of sample $\mu \mathrm{g} / \mathrm{ml}=$

Area of sample /area of standard $\times$ Con.of standard $\times$ dilution factor

TABLE III: FLAVONOIDS CONTENTS IN QARADAX HAWTHORN FRUITS[1]

\begin{tabular}{|l|l|c|c|c|c|c|c|c|}
\hline no & Flavor- noids & Rt/m & area/standard & df & area/sample & conc. $\boldsymbol{\mu g} / \mathbf{m l}$ & conce. of sample & \% \\
\hline 1 & Neoategolic acid & 1.98 & 25007 & 3 & 30716 & 25 & 92.1222 & 9.59131302 \\
\hline 2 & Kaempferol & 2.66 & 41927 & 3 & 63380 & 25 & 113.3756 & 11.8041154 \\
\hline 3 & Querecetin & 3.38 & 50898 & 3 & 78125 & 25 & 115.1199 & $\mathbf{1 1 . 9 8 5 7 2 5 1}$ \\
\hline 4 & Nonacosan-10-01 & 4.07 & 41431 & 3 & 72802 & 25 & 131.7890 & $\mathbf{1 3 . 7 2 1 2 2 5 2}$ \\
\hline 5 & Apigenin & 5.14 & 21142 & 3 & 49406 & 25 & 175.2649 & $\mathbf{1 8 . 2 4 7 7 2 0 7}$ \\
\hline 6 & Luteolin & 6.23 & 23729 & 3 & 20738 & 25 & 65.5464 & 6.82436794 \\
\hline 7 & Rutin & 6.99 & 44471 & 3 & 50339 & 25 & 84.8963 & 8.83899094 \\
\hline 8 & Hypersoide & 7.98 & 21863 & 3 & 27170 & 25 & 93.2054 & 9.70409152 \\
\hline 9 & Vitexin-rahmnose & 8.75 & 31853 & 3 & 37865 & 25 & 89.1557 & 9.28245002 \\
\hline & Total & & & & & & 960.4754 & \\
\hline
\end{tabular}


TABLE IV: FLAVONOIDS CONTENTS IN HAWRAMAN HAWTHORN FRUITS[1]

\begin{tabular}{|l|l|l|c|c|c|c|c|c|}
\hline no & Flavor- noids & Rt/m & area/standard & df & area/sample & conc. $\boldsymbol{\mu g} / \mathbf{m l}$ & conce. of sample & \% \\
\hline 1 & Neoategolic acid & 1.98 & 25007 & 3 & 28535 & 25 & 85.5810 & 10.5032432 \\
\hline 2 & Kaempferol & 2.66 & 41927 & 3 & 75569 & 25 & 135.1796 & $\mathbf{1 6 . 5 9 0 4 0 6 4}$ \\
\hline 3 & Querecetin & 3.38 & 50898 & 3 & 85808 & 25 & 126.4411 & $\mathbf{1 5 . 5 1 7 9 4 4 7}$ \\
\hline 4 & Nonacosan-10-01 & 4.07 & 41431 & 3 & 81477 & 25 & 147.4928 & $\mathbf{1 8 . 1 0 1 5 9 1 2}$ \\
\hline 5 & Apigenin & 5.14 & 21142 & 3 & 24859 & 25 & 88.1858 & 10.8229268 \\
\hline 6 & Luteolin & 6.23 & 23729 & 3 & 0 & 25 & 0.0000 & 0 \\
\hline 7 & Rutin & 6.99 & 44471 & 3 & 14524 & 25 & 24.4946 & 3.00619040 \\
\hline 8 & Hypersoide & 7.98 & 21863 & 3 & 29265 & 25 & 100.3922 & 12.3209987 \\
\hline 9 & Vitexin-rahmnos & 8.75 & 31853 & 3 & 45460 & 25 & 107.0386 & 13.1366983 \\
\hline & Total & & & & & & 814.8058 & \\
\hline
\end{tabular}

The separation occurred on liquid chromatography Shimadzu 10AV-LC equipped with binary delivery pump model LC-10AV Shimadzu, the eluted peaks were monitored by UV-Vis 10A-SPD spectrophotometer.

\section{CONCLUSION}

The two types of hawthorn leaves [Zalan and Qaradax] in Iraqi Kurdistan region are rich source of Hypersoide and Vitexin- rahmnose (according to HPLC analysis) which both are the main effectives flavonoids in Hawthorn leaves as mentioned in the introduction for medical purpose for example Vitexin (VII) is a class of nature lignan compounds, whose action and anticancer effect is mediated by the mechanisms different from the classic lignans. Vitexininduced antitumor effect.

\section{ACKNOWLEDGMENT}

We are very much indebted to the department of chemistry, school of science in the faculty of science and faculty of Agriculture at the University of Sulaimani for providing the facilities, encouragement and financial support during the investigation. Also thanks due to the University of Baghdad for obtaining HPLC techniques for identification of the chemical components in all hawthorn leaves and fruits.

\section{REFERENCES}

[1] B. A. H. Ameen, S. N. Majeed, and D. A. Abdul, Asian Journal of chemistry, March 2012.

[2] Z. Zuo, L. Zhang L. Zhou, Q. Chang, and M. Chow, "Hawthorn Fruit Extracts Hawthorn Leaves Extracts," Life Science, vol. 79, no. 26, pp. 2455-2462, 2006.

[3] W.-L. Zhang, M. Gao, and S.-L. Shi, "Drug Family in Hospital of Ningbo University, Ningbo," Chinese Archives of Traditional Chinese Medicin, vol. 05, 2011.

[4] M. H. Pittler, K. Schmidt, and E. Ernst, American Jouranal of Mecine, vol. 114, no. 8, pp. 665, 2003.

[5] V. Jakstas, V. Janulis, and J. Labokas, Journal of Medicina (Kaunas), vol. 40, no. 8, pp. 750-752, 2004
[6] L. Mazzafera, "Rutin synthase in fava d'anta: Purification and influence of stressors," Canadian journal of plant science, vol. 89, no. 5, pp. 895-902, 2009.

[7] S. Kreft, M. Knapp, I. Kreft, "Extraction of rutin from buckwhea (Fagopyrum esculentum Moench) seeds and determination by capillary electrophoresis," Journal of. Agriculture \& Food Chemistry, vol. 47, no. 11, pp. 4649-52, November 1999.

[8] Herbal Extracts. [Online]. Available: http://www.herbalextractsplus.com/rutin.cfm.

[9] S. Chang, C. Tan, E. N. Frankel, and D. M. Barrett, "Low-Density Lipoprotein Antioxidant Activity of Phenolic Compounds and Polyphenol Oxidase Activity in Selected Clingstone Peach Cultivars," Journal of Agriculture \& Food Chemistry, vol. 48, pp. 147-151, 2000.

[10] A. Urbonaviciute et al. "capillary electrophoretic analysis of flavonoid in hawthorn ethanolic extract," Journal of chromatography A vol.1112, issue 1-2, pp. 339-344, 2006.

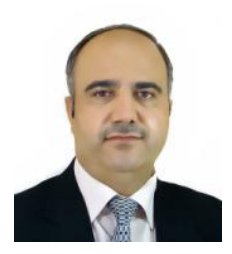

Baram A. Hamah Ameen lives in Kurdistan region of Iraq in a city called Sulaimani ( Soulaimaniyah) $400 \mathrm{~km}$ north-east of capital of Iraq( Bagdad), He was born in the same city on January 111970 . His Ph.D. is in organic chemistry, he educated in University of Louis Pasteur, Strasbourg, France on June 6 2005, natural products, organic synthesis and stereoslective synthesis are my major field in research. Know, He is working in Department of Chemistry at the Sulaimani University in Kurdistan region of Iraq.

He is a member of scientific committee of the department and member of HCDP ( human capacity developing program) in ministry of higher education of KRG (Kurdistan Regional Government), He is Lecturer in his field for both undergraduated and postgraduated student since 1994, he has published more than 10 papers in different local and international journals like : Tetrahydron Lett.44, (2003), 8501-8503, J.Of Zanko Salahddin A,vol 14, no.1, 2003, Journal of Molecular CatalysisA: Chemical 273(2007)92-98, Springer, in process, march 2012.

His current researches are on environmental pollution by organic pollutant in Kurdistan region and natural products components in the same region. He prepared some manual books of practical organic chemistry for chemistry students 2005 in Sulaimani..Dr.Baram is member of French Society of Chemistry (Societe francaise de chimie) and Kurdistan chemical and physical society and also in Kurdistan teacher union. 